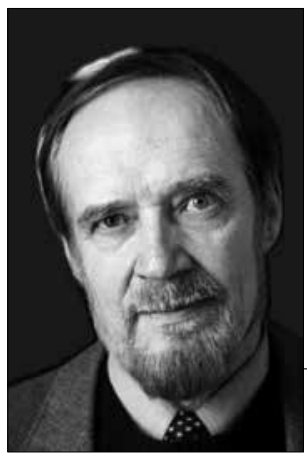

https://doi.org/10.24101/logos.2020.22

Gauta 20200319

\title{
ANTANAS ANDRIJAUSKAS
}

Lietuvos kultūros tyrimų institutas, Lietuva

Lithuanian Culture Research Institute, Lithuania

\section{GENIALUMO IR PSICHIKOS SUTRIKIMŲ SANTYKIŲ PROBLEMA PSICHOPATOLOGI- NÉSE MOREAU DE TOURS, LAMBROSO IR NORDAU KONCEPCIJOSE}

\author{
The Problem of Genius and Psychical Disorder \\ in Psychopathological Conceptions of Moreau de Tours, \\ Lambroso and Nordau
}

\author{
SUMMARY
}

The article examines the various conceptions dealing with the interrelationship between genius and psychical disorder. These conceptions were developed by three most influential representatives of psychopathology: Moreau de Tours, Lambroso and Nordau. The article highlights the peculiarities of these authors' theoretical and methodological approaches, their views on the problems of artists' creative potential and the process of artistic creativity. The focus of the article is on: the connections between these authors and the earlier non-classical tradition of the philosophy of art, the critical discussion of principal ideas and theoretical and methodological attitudes, and the relations with other influential theories that deal with psychopathological problems.

\section{SANTRAUKA}

Straipsnyje pagrindinis dèmesys sutelkiamas į trijų įtakingiausių psichopatologijos atstovų Moreau de Tours, Lambroso ir Nordau, tyrinëjančiu genialumo ir psichinių sutrikimu santykius, koncepcijas. Atskleidžiamas šiu psichiatrų teorinių ir metodologinių prieigu savitumas, požiūriai į menininko kūrybinio potencialo ir meninès kūrybos proceso problemas. Daugiausia dèmesio tekste sutelkiama į šių koncepcijų ryšius su ankstesne neklasikinės meno filosofijos tradicija, kritinị pagrindinių idëjų bei teorinių ir metodologinių nuostatu aptarimą, sąsajas su kitomis įtakingiausiomis psichopatologines problemas gvildenančiomis teorijomis. 


\section{IVADAS}

Psichopatologijos terminas Vakaru humanistikoje atsirado XIX a. pabaigoje kaip klinikinés psichologijos sinonimas. Galutinai ji itvirtino savo veikaluose Sorbonos ir Collège de France profesorius ThéoduleArmand Ribot (1839-1916), kuris psichopatologiją traktavo kaip greta genetinès ir eksperimentinės besiskleidžiančią svarbią psichologijos šaka, savo tyrinejjimo objektu ir metodais artimą teorinei psichiatrijai. Vadinasi, jo isitikinimu, psichopatologijos negalima visiškai sutapatinti su psichiatrija, kadangi joje daug dèmesio skiriama ne tik terapiniams, bet ir teoriniams psichiniu ligu aspektams. Ribot pastangomis Sorbonos universitete ir Collège de France buvo isteigtos atskiros psichopatologijos problemas gvildenančios katedros (Ribot 1895). Panašiai psichopatologijos uždavinius ir tyrinejjimo objektą suprato ir Karlas Jaspersas. Apibendrindamas psichinès ligos ir genialumo santykius, jis teigè, kad šios ligos tèkmès ir poveikio negalima laikyti būtina genialios kūrybos prielaida, kuri visiškai lemia meninès kūrybos procesą ir jo rezultatus.

\section{PSICHOPATOLOGINIŲ TEORIJŲ IŠTAKOS IR MOREAU DE TOURS APIE GENIJAUS PATOLOGIŠKUMA}

Neklasikinès meno psichologijos raida suaktualino vèlesnių mąstytojų domejjimąsi meno psichologijos ir psichopatologijos problematika: menininko ir psichinių ligų santykiais, jo kūrybiniu potencialu, meninès kūrybos procesu paslaptimis ir ivvairių psichinių patologijų poveikiu kūrybai. Skirtingų neklasikinę meno filosofiją tęsiančių ar su ja konfrontuojančių krypčių atstovai sutelkè savo dèmesi i i ivairias aktualejjančias meno psichopatologijos problemas. Iš čia išsirutuliojo îvairios didžiulius ginčus sukèlusios, genialumą ir psichines neurozes suartinančios kryptys ir koncepcijos. Didžiausią poveiki tolesnei Vakaru humanistikos raidai turejo trys pagrindinès kryptys: psichopatologine, psichoanalitine ir pozityvistine. Kiekviena ju turèjo savas ištakas ir vadovavosi skirtingomis teorinèmis ir metodologinèmis nuostatomis.
Dabar išsamiau aptarsime XIX a. pabaigoje ir XX a. pradžioje iškilusią psichopatologine krypti, jungiančią daugelio kitų, ypač romantinės ir neklasikinès meno psichologijos, idèjas. Jos šalininkų Louis François Lélut (1804-1877), JacquesJoseph Moreau de Tours (1804-1884), Henri Sentoux (1835-1880), Cesare Lambroso (1835-1909), Georges'o Hirtho (1841-1916), Maxo Simono Nordau (18491923), Marcelio Réja (Paul Meunier, 1873-1957), Wilhelmo Lange-Eichbaumo (1875-1949), Ernesto Kretschmerio (18881964) koncepcijos išsiskyrė teorinių prieigu ivvairove, o neretai ir idejų eklektiškumu. Plètodami Schopenhauerio idèjas, šios krypties atstovai siekè teoriškai pagrịsti glaudų genialumo ir ivvairių psichinès patologijos apraišku ryšį. Genijuose ir išskirtinio talento asmenybėse, ju elgesio manieroje, mąstymo stiliuje, santykiuose su visuomenès normomis, kū- 
rybos pobūdyje jie izžvelgè sąsajas su ivairiomis psichinemis ligomis sergančiais žmonėmis. Todèl genialių kūrëjų meninès kūrybos ištakas ir apskritai genialumo fenomeną traktavo kaip ivairių psichinès patologijos formų (maniakiškumo, šizofrenijos, somnambulizmo, demonizmo ir pan.) pasireiškimą.

Šios idèjos iškart sukèlè didžiuli ìvairių humanistikos sričiu atstovų ir menininkų susidomėjimą. Todèl XIX a. antroje pusèje ir pirmaisiais $X X$ a. dešimtmečiais dienos šviesą išvydo didžiulis srautas knygu ir straipsniu, kuriuose, remiantis neklasikine ir psichopatologine metodologija, buvo interpretuojama daugybès garsiu, ivairiu psichikos sutrikimu paveiktu menininku kūryba. Minèti veikalai glaudžiai siejosi su intensyviai besiplètojančios psichiatrijos raida, kurios šalininkai padare svaru innašą i žmogiškos psichikos sutrikimu ir ju poveikio įvairioms kūrybinès veiklos formoms tyrinèjimus. Šias idejjas skleidžiantys mokslininkai siekè teoriškai pagrịsti glaudu genialumo ir įvairiu psichikos ligu ryšĭ išryškinti tuos kūrybingos asmenybės psichinės sandaros, charakterio ir kūrybinès veiklos panašumus, kurie patvirtintu jų teoriniu nuostatu pagrịstumą.

Remdamasis Schopenhauerio analogijomis tarp geniju ir psichiniu ligoniu gyvensenos, pasaulio suvokimo panašumu ir ilgametès terapinès praktikos bei stebėjimų duomenimis, XIX a. viduryje įtakingiausias šios krypties pradininkas prancūzu gydytojas ir psichiatras J.-J. Moreau, plačiau žinomas kaip Moreau de Tours (1804-1884), savo veikaluose Études psychiques sur la folie (Psichi- niai beprotybès tyrinèjimai, 1840), Recherches sur les aliénés en Orient (Beprotybès Rytuose tyrimai, 1843) ir De l'Identité de l'état de rêve et de la folie (Svajoniu būsenos ir beprotybes tapatumas, 1855), Psychologie morbide (Liguista psichologija, 1856) išplètojo vientisą psichopatologinę teoriją. Minèti jo veikalai išsiskyrè ne tik išsamia, gerai struktūruota empirine analize, bet ir taikliais psichinių sutrikimų aprašinèjimais bei stebejjimais paremta ivvairiu psichiniu ligu interpretacija.

Moreau de Tours studijavo mediciną Tūro universitete, vèliau tęsè medicinos studijas Paryžiuje Sorbonoje, kur 1830 $\mathrm{m}$. apgynè intelekto sutrikimams skirtą disertaciją. Nuo 1836 iki 1840 m. daug keliavo po ìvairius Rytu kraštus, kuriuose domėjo indišku kanapių poveikiu žmogaus psichikai, tyrinejjo ju poveiki ivairiais psichinès patologijos atvejais. Aiškinosi, kokiu tikslu ir kaip persai, turkai, egiptiečiai naudoja savo reikmèms opiumo poveiki žmogaus organizmui ir elgesiui. Intoksikacija hašišu mokslininkui buvo unikali pagalbinè priemonè, padedanti tirti ịvairius žmogaus psichikos pokyčius. Tai buvo vienas pirmujjų fanatiškai atsidavusių savo profesijai, $i$ teorinius apibendrinimus linkusiu, kryptingai psichiatrijos ir psichopatologijos problemas tyrinejusiu mokslininkų. Dirbdamas ivairiose garsiose Prancūzijos psichiatrinèse klinikose, jis ne tik daug metu kryptingai tyrinëjo narkotikų aktyvumo poveikị centrinei nervų sistemai, tačiau ir kruopščiai suklasifikavęs, išanalizavęs juos, sistemingai užrašinėjo svarbiausius savo pastebejjimus. Vèliau tai jam tapo svarbia empirine 
atrama gvildenant ivairius savo psichopatologinès koncepcijos aspektus.

Tęsdamas romantikų ir neklasikinès filosofijos atstovu psichopatologines idèjas, Moreau de Tours atvirai pareiškè, kad tikro genijus kūrybinè raiška yra neatsiejama nuo beprotybès: „Mane verčia be jokių užuolankų atvirai pasakyti, $\mathrm{kad}<\ldots>$ genijus yra genijus, kaip kad ir beprotybė yra beprotybè. Bet tai yra ne tas pats pasakymas, o aš teigiu, kad genijus ir beprotybė turi tą pačią organinę kilmę“ (Moreau de Tours 1856: 42). Esminis asmenybès išsiskyrimas savo idèjomis, sugebèjimais, ekscentriškumu, energija, gyvenimo efektyvumu iš kitu liudija, mokslininko giliu įsitikinimu, jos tiesioginę priklausomybę „nuo tụ sąlygu, kurios lemia psichinius sutrikimus, kurie akivaizdžiai regimi beprotybès ir idiotizmo atvejais". Programiniame veikale Psychologie morbide jis teigè, kad "genijus ir idiotas yra tarsi tų pačiu dviejų pirmapradžių ir svarbiausių tos pačios neurozės apraiškų sujungimas" (Moreau de Tours 1856: 427). Ir vèliau patikslino savo minti̇, kad daugybės genialių žmoniu psichikos sandara, taip pat kaip ir idiotu, išsiskiria, lyginant su paprastais žmonėmis, ypatingu nervingumu, jautrumu ir dirglumu, kuris yra anapus sveikatos, vadinasi, svetimas normalios psichinès struktūros žmonėms.

Psichiatro issitikinimu, tiek genijui, tiek ir psichiniam ligoniui būdingas toks pat aistringas nekontroliuojamas smegenų veiklos sujaudinimas, kuris žaibiškai sukelia daugybę ivvairiausių asociacijų ir nepaprastai greitai besiskleidžiančiu idèjų bei koncepcijų. Iš čia kyla galingi im- pulsai spontaniškiems vaizduotės polèkiams, originaliems minties posūkiams, kuriuose derinamos įvairios kūrybinès raiškos formos; jos kupinos nenuspejamumo, sunkiai prognozuojamų idèjų, asociaciju ìvairovės, gausybės gyvybingu prisiminimu, girdimu garsų proveržių ir vaizduotės blykstelèjimų.

Kita vertus, Moreau de Tours, kaip ir jo amžininkas F. Galtonas, domèjosi psichinių ligų paveldimumo problemomis, gilinosi i ịvairių garsių kūrèjų ir menininku giminiu intelektualines biografijas, kuriose apčiuopè ligu paveldimumo pėdsakus. Jis taip pat buvo vienas įuūrèju garsaus Paryžiaus intelektualų ir menininkų židinio Club des hachichiens („Hašišo myletojų klubo“), kuriame nuolat lankèsi Théophile Gautier, Charles Baudelaire'as, Gérardas de Nervalis, Eugène Delacroix, Alexandre'as Dumas ir daugybẻ kitų ižymybių. Vadinasi, jis turëjo galimybes daug dešimtmečiu tiesiogiai stebèti ir bendrauti su daugybe pirmo ryškumo Prancūzijos kultūros ir meno žvaigždžių. Lankydamasis šiame klube, Moreau de Tours sistemingai stebejjo ir detaliai aprašinejjo narkotinių medžiagu poveiki sau ir kitiems klubo nariams. Tie aprašymai, paremti skvarbiu profesionalaus psichiatro žvilgsniu, ryškiai skyrèsi nuo to, ką mes regime vaizdinga kalba parašytuose Baudelaire'o ir Gouthier šia tema paskelbtuose tekstuose. Šiuos narkotinių medžiagu poveikio žmonėms stebejjimus ir tyrinëjimus bei narkotines medžiagas psichiatras siekẻ kryptingai panaudoti konkrečiu psichikos sutrikimu ir ligu gydimui, kadangi narkotinių medžiagu poveikis žmonių psichikai buvo 
panašus i psichikos ligomis sergančių asmenu haliucinacines reakcijas.

Jis ne tik plačiai rėmèsi savo negausių pirmtaku tyrinèjimais, tačiau ir, nuolatos darydamas ivvairius eksperimentus, rèmėsi savo ilgametės terapinės praktikos bei stebejjimu psichiatrinèse kinikose duomenimis, kuriuos nuolatos kritiškai analizuodavo. Šio mokslininko darbai išsiskiria subtiliomis įžvalgomis. Jo įsitikinimu, esminis ir ryškus kiekvienos konkrečios asmenybės išsiskyrimas savo idèjomis, sugebejimais, ekscentriškumu, energija, kūrybinio gyvenimo efektyvumu iš kitų žmonių liudija tokios išskirtinès asmenybès tiesioginę priklausomybę nuo sąlygu, lemiančiu konkrečius psichinius sutrikimus, kurie „akivaizdžiai regimi beprotybès ir idiotizmo atvejais". „Intelektualiniai sugebèjimai,- aiškina jis,- slypi liguistose nervų sistemos būsenose, kurios paveldimos ir, sakant daugiau, yra palankiausios sugebèjimu plètotei“ (Moreau de Tours 1856: 447).

Moreau de Tours buvo įsitikinęs, kad fizinés psichinės ligos priežastys yra svarbesnès nei tuo metu daugelio jo kolegu akcentuojamos moralines. Todèl moralinius psichinių ligų aspektus traktavo kaip mažiau reikšmingus, vadindamas juos netgi "atsitiktiniais“ palyginti su organiškais fiziniais. „,Beveik visuomet, rašè jis, - regimas daugiau ar mažiau aiškiai išreikštas organiškas polinkis - tai akivaizdu $\langle\ldots>$. Tai mums galbūt gali paaiškinti, kodèl, kaip mes mateme, moralinès priežastys taip lengvai sukelia protinius sutrikimus, o tos pačios prigimtinès priemonès būna tokios bejejgès siekiant jas išgyventi. Moreau de Tours ignoruoja patikimų faktų, patirčių ir intymių stebejimų rezultatus. Pakaks samprotauti apie beprotybès kliedesiu paslaptis" (Moreau de Tours 1856: 398).

Mokslininko psichopatologinių reiškiniu tyrinëjimams būdingas polinkis ị plačius teorinius apibendrinimus, smulkesniu psichologinès analizės procesų detaliu ignoravimas ilgainiui susilaukè pagristos kitu psichiatru kritikos. Pavyzdžiui, Frédericas Grosas teigè, kad Moreau de Tours idejos „per dažnai pateikiamos kaip didžiulè vientiso organizmo doktrina. Tačiau jo gruboki teiginiai menkiau išreiškia vienareikšmio priežastingumo dogmas, mažiau apibūdina faktinius jo metodo postulatus: norą išvengti žabangu ",spekuliaciju“", „magiškos metafizikos", "ontologinio rūko" triukų. Šiu abstrakčiu konstrukciju pabaiga, kai protas pasimeta tikèdamasis jas atpažinti“ (Gros 1997: 101-102).

Daug bendravęs su Paryžiaus meninio elito atstovais Moreau de Tours nebuvo abejingas ir menininku kūrybinio potencialo bei meninès kūrybos proceso problemoms. Gvildendamas poetinès kūrybos ir psichinès patologijos ryšius, jis įžvelgè sąsajas tarp kūrybinio įkvėpimo ir maniakinių būsenų. Jų panašumai reiškèsi greitomis neprognozuojamomis asociacijomis, lakios vaizduotès ir fantazijos polèkiais, peržengiančiu normos ribas jausmingumu. Išanalizavęs daugelio garsių menininkų biografijas neurotinių simptomų aspektu, Moreau de Tours iškẻlè natūraliai iš jo tyrinèjimų visumos iškylantį klausimą: Kas yra genijus: aukščiausias intelektinès veiklos nec plus ultra pasireiškimas ar neurozės forma? 


\section{GENIALUMAS LOMBROSO PSICHOPATOLOGINĖJE KONCEPCIJOJE}

İ ši Moreau de Tours iškeltą klausimą mėgino surasti atsakymą kitas garsus italu psichiatras, antropologas ir kriminalistas Cesare Lombroso (1836-1909). Šis demokratinių pažiūrų mokslininkas, jaunystëje aktyviai dalyvavęs italų nacionalinio išsivadavimo sajūdyje, vèliau išgarsejjo savo naujais psichopatologines problemas gvildenančiais psichiatrijos metodais. Jis vadovavo psichiatrinei ligoninei Pezaro mieste, leido tęstini psichiatrijos problemoms skirtą žurnalą. Skandalingai pagarsejjusiose knygose Genio e follia (Genijus ir beprotybe, 1864), Studi clinici sulle mallatie mentali (Klinikiniai psichikos sutrikimu tyrimai, 1865), Genio e degenerazione (Genijus ir išsigimimas, 1897), Delitti vecchi e delitti nuovi (Seni ir nauji nusikaltimai, 1902) Lambroso sieke teoriškai pagrịsti biologini nusikaltimu neišvengiamumą. Tačiau ne mažiau reikšmingas jị dominusių problemų laukas siejosi su išsamiu genialumo ir psichinès patologijos sąsajų tyrinëjimu.

Pirmiausia norėdamas ne tik teoriškai, tačiau ir statistiniais duomenimis pagristi genialių menininkų kūrybos ir psichinių susirgimu ryš pasitelkè didžiulę ivvairiomis psichikos ligomis sergančiu 107 žmoniu grupę. Kiek mažiau nei pusė ju (46) kultivavo ¿̇vairias meno rūšis, o profesionalių menininku visoje tyrimams pasirinktoje grupejje buvo 18. Atlikęs įvairių psichiniu ligoniu grupių lyginamuosius tyrinèjimus ir teoriškai apibendrinęs stebẻjimu rezultatus jis, anksčiau nei psichoanalitinès teorijos kūrëjas S. Freudas, prièjo principinès išvados, kad psichines ligas ir traumas galima traktuoti kaip galingus meniniu gabumu sklaidos stimulus. Peremęs Schopenhauerio genijaus siejimo su psichine liga idejja jis genialumą aiškino kaip ypatinga "išsigimimo psichozès" forma, priskiriama prie epileptiniu susirgimu grupés. Nors ir garsiai to nedeklaruodamas, jis skleide mintis apie išskirtinio talento ir genialių žmonių kūrybos nuostatų esmini priešingumą tam, kas respektabilioje visuomeneje yra laikoma normaliu.

Geniali asmenybè, kaip ir psichinis ligonis, Lambroso i̇sitikinimu, pirmiausia išsiskiria pabrèžtinai jautria psichine struktūra, išplètota vaizduote, beveik liguistu imlumu išorinio pasaulio įspūdžiams ir pojūčiams, kurie neprieinami eiliniam žmogui. „Jei mes dabar paméginsime spręsti klausimą - kame slypi fiziologinis skirtumas genialaus ir paprasto žmogaus, - rašo jis, - tai, remdamiesi autobiografijomis ir stebejjimais, surasime, kad pagrindinis skirtumas tarp ju glūdi subtilesniame ir beveik liguistame pirmojo jautrume ispūdžiams" (Lambroso 1997: 19-20). Šios artimos psichiniams ligoniams savybès čia traktuojamos kaip dèkinga medžiaga meninei kūrybai. Kitą ne mažiau svarbų genialiu žmonių ir psichinių ligonių panašuma, skiriantį nuo daugybès paprastų žmoniư psichiatras regi galvos smegenims būdingame susijaudinime, kuri aiškina fiziologiškai kaip padidintą kraujo smegenu maitinimą. Jo įsitikinimu, genijaus karštligiška būsena meninès kūrybos metu primena maniakišką susijaudinimą ir psichiatru atpažizstamus paranojos bruožai. Todèl tarp genijaus, kuriančio savo 
nemirtingus kūrinius, kūrybinès veiklos ir susijaudinusio psichinio ligonio būsenos italu psichiatras regi tiesioginę analogija, o igimtą genialumą sieja su potencialiais polinkiais i psichines anomalijas. „Nekyla jokios abejonès,- apibendrina jis, - kad tarp priepuolio metu pamišusio ir genialaus žmogaus, apgalvojančio ir kuriančio savo kūrini, yra visiškas panašumas" (Lambroso 1997: 16).

Siedamas kraujo poveikio smegenu veiklai ypatumus su geografine aplinka, šiluma, gamtinio reljefo pobūdžiu, metų sezonais Lambroso kartu klojo pamatus vèlesnèms gamtinès aplinkos ir biologinių ritmu teorijoms. Jis kruopščiai parengè sudėtingas išklotines ir skaičiavimus pagal skirtingus intelektualinio, meninio kūrybingumo regionus ir nustatinèjo konkrečius metų mènesius, aiškindamasis, kur yra tie žemès rutulio taškai, kuriuose statistika fiksavo daugiausia genialių žmonių išskirtinių kūrybingumo raiškos pavyzdžiu ir atradimų. Analizuodamas skirtingų metų laiku poveikị kūrybingumo sklaidai, pavasari Lambroso aptiko daugiau genialios dvasios skrydžių nei šaltą žiemą.

Lygumų ir ypač pelkių bei drégnas šalis, remdamasis statistiniais duomenimis, Lambroso aiškino kaip nepalankias vietoves genialių asmenybių kūrybiškumo sklaidai ir, priešingai, kalvotuose ir ypač pajūriu šilto klimato regionuose aptiko genialių asmenybių koncentracijos vietas. Italijoje, pavyzdžiui, tokia geniju koncentracijos vietoves jis aptinka Genujos, Neapolio, Sicilijos, Florencijos apylinkèse. Kita vertus, lygindamas greta esančias kalvotoje vietoje Florenciją ir žemumoje esantį universitetini miestą
Piza jis, nekreipdamas dėmesio i̇ svarbią kultūrinę bei meninę aplinka, konstatavo, kad pirmojoje gimè nepalyginti daugiau išskirtinio talento asmenybių. Tačiau tokios netgi menamai kruopščiais statistiniais duomenimis paremtos mokslininko išvados ne visuomet yra patikimos.

Lyginamuoju aspektu analizuodamas genialumo apraiškas ìvairiose tautose Lambroso nustate tiesioginę priklausomybę, jo požiūriu, talentingiausioje žydu tautoje tarp genialiu asmenybiu ir psichinių ligoniu gausos. Tai kaina, kuria, mokslininko i̇sitikinimu, žydu tautybès atstovams tenka mokèti už neiprastai didelį talentingų ir genialių žmonių skaičių. Išvados čia paremiamos dviejų skirtingu pirmtaku pateiktais statistiniais duomenimis: pirmojo rodo, kad Italijoje psichiatrinèse ligoninėse žydu kilmès pacientu yra keturis, o kito - netgi dar daugiau nei keturis kartus daugiau nei katalikų. Šis dviejų kraštutinumų santykinis dydis, Lambroso isitikinimu, statistiniais faktais patvirtina jo koncepcijos teisingumą. Tačiau mokslininko dèmesio nuošalyje liko kitos šių problemų tyrinèjimui svarbios žydų integracijos į italų visuomenę, taip pat tarp žydu paplitusios artimu giminiu vedybu problemos, kurių išsamesnis aptarimas daugiau ir išsamiau paaiškintų ši klausimą. Tiesa, tenka pripažinti, kad Lambroso atkreipè dèmesį ir ị išskirtinį vaidmeni paveldimu veiksniu tarp psichiniu ligonių, kurie, skirtingų mokslininkų duomenimis, darè itaką nuo 85 iki 88 iš šimto tyrinèjamu psichinių ligonių.

Išskirtinio talento ir genialioms asmenybėms Lambroso priskyrè daugeli psichiniams ligonims būdingų ir eilinį mies- 
čioni šokiruojančių charakterio savybių. Jiems neretai būdingas perdètas impulsyvumas, hipertrofuotas savigarbos jausmas, nepagrịstas ittarumas, nemotyvuotas greitas susierzinimas. Kurdami svajose gražius ir harmoningus lakios vaizduotès nutapytus pasaulius, realiame gyvenime jie savo ekscentriškais poelgiais ir veiksmais dažnai supantiems žmonėms tampa sunkiai pakenčiami. Tokioms asmenybėms būdingos su fiziologinèmis žmogaus kūno funkcijomis susijusios paprastus žmones šokiruojančios savybès: perdètas impulsyvumas, nepagristas ittarumas, greitas susierzinimas, banguojanti ekstazès ir atonijos, t. y. susijaudinimo, kūrybinių jẻgų antplūdžio ir jų nuosmukio kaita, kuri dažniausiai reiškiasi daugelio išskirtinio talento ir genialių kūrèjų kasdieniame gyvenime. „Visi, kam teko reta laimè gyventi genialių žmonių aplinkoje, stebėdavosi jų sugebejjimu iškreipti i blogają pusę kiekvieną supančių poelgi, visur regèti persekiojimus ir visame kame surasti pagrindą giliai, begalinei melancholijai. Šis sugebejjimas nulemtas būtent stipresnių protinių galių išsivystymo, mat jomis apdovanotas žmogus daug greičiau suranda tiesą ir kartu lengviau sugalvoja savo kamuojančio paklydimo melagingas prielaidas ir argumentus. Iš dalies niūrus genijaus žvilgsnis į aplinkinius priklauso ir nuo to, kad būdami novatoriais intelektualinèje sferoje, jie su neįveikiamu tvirtumu išsako savo įsitikinimus, svetimus visuotinai priimtiems požiūriams, ir kartu atstumia nuo savęs daugumą žmonių (Lambroso 1997: 23). Itemptas fizines ir protines jègas alinantis kūrybinis darbas neišvengiamai rei- kalauja kompensacijos, t. y. poilsio. Esant ypatingam asmenybès jautrumui, begalinis genialios asmenybès atsidavimas kūrybai, pragariškas darbas su užplūdusiomis mintimis ir idejomis be deramo poilsio dažnai tapdavo neatsakingu savo biologinių gyvybinių organizmo išteklių sekinimu ir išeikvojimu. Tai savo ruožtu išprovokuodavo naujus persitempusio nuo ittampų psichinių organizmo ligu simptomus, todèl šis procesas neretai igaudavo patologini pobūdị ir lemdavo persitempimą bei destruktyvias pasekmes psichikai.

Ir vis dèlto pagrindinè išskirtinių asmenybių didejjančios melancholijos, depresijos ir nepasitenkinimo gyvenimu priežastimi, italų psichiatro įsitikinimu, buvo universalus dinamizmo ir pusiausvyros dèsnis, valdantis ir sudètingą žmogau psichikos ir nervų sistemą. Tai dèsnis, pagal kuri po perdètos kūrybinès energijos jègos iškrovos neišvengiamai išryškèja jos nuosmukis (Lambroso 1997: 23). Taigi čia pasiteisino elementari gyvenimo tiesa, kad pasaulyje viskas yra subalansuota ir už viską reikia mokèti savo kainą. Todèl melancholija, nusivylimas, drovumas, nedrąsumas, egoizmas Lambroso koncepcijoje traktuojama kaip neišvengiamas ,žiaurus mokestis už tuos aukščiausius protinius sugebejjimus, kuriuos išeikvoja, panašiai kaip piktnaudžiavimas jausminiais malonumais veda prie lytinès sistemos išbalansavimo, impotencijos ir nugaros smegenu ligos" (Lambroso 1997: 24).

Fiziologiniu aspektu Lambroso taip pat tyrinèjo genialių ir pamišusių žmonių kūno, psichikos sandaros, charakterio, elgesio manieros, kūrybinio poten- 
cialo ir daugybės kitų išorinių bei vidinių bruožų panašumus. Ir čia jo teorinèse nuostatose iškilo anksčiau minètas universalus visuotinès harmonijos ir subalansuotumo principas, kuris aprépe visus gamtos ir žmonių būties aspektus. Todèl gamta, ši baisi ir nenumaldoma kraštutinumų naikintoja, jo tvirtu įsitikinimu, tarsi nepakenčia genijų; kai tik skleidžiasi koks nors reikšmingas talentas, jis išperkamas nevaisingumu, silpnu gyvybiškumu arba epilepsija. Šiuos teiginius Lambroso grinde pasitelkdamas W. Sheakspaire'o, F. Dostojevskio ir H. Ibseno pavyzdžius. Italų psichiatras taip pat siekè pagristi psichinėmis ligomis sergančiu genijų atsiradimo gausą tose meno rūšyse, kuriose ypatingą svarbą igauna asmenybės subtilumas, emocionalumas ir jautrumas. Tokia meno rūšimi, tęsdamas neklasikinès meno psichologijos tradicija, skelbė muzika, kurioje aptiko ištisą plejadą garsių įvairiomis psichinėmis ligomis sergančiu muzikantų (Mozartas, Schumanas, Beethovenas, Donizetti, Pergolesi, Hendelis, Gliuckas).

Kita vertus, nuolatos pabrèždamas patologinę genialių asmenybių prigimtį, Lambroso apeliavo i juc jausminguma, nervingą temperamenta, impulsyvumą, intensyvu pasaulio suvokimo liguistuma, aiškindamas tai ne kaip išsekimo ar psichologinio nuovargio požymius, o kaip esminę genialios kūrèjo individualybès ir charakterio bruožą. Vadinasi, kad ir kaip paradoksaliai atrodo išvada, sutapatinanti genialuma ir neuroze, ji, anot Lambroso, turi visiškai realu pagrinda genialiu žmoniu psichikos sandaroje. Todèl išskirtinio talento menininkas ir genijus jo koncepcijoje iškyla kaip ypatinga tita- niška morbus sacer, t. y. šventos ligos apraiška. Tai lèmé principini i̇sitikinimą, kad psichinis ligonis gali kurti visaverčius meno kūrinius.

Galiausiai apibendrindamas savo genialumo ir psichinès patologijos sąsaju tyrinejjimus Lambroso priëjo logišką išvada, kad genialumo apskritai negalima sutapatinti su neuroze, nors "fiziologiniu požiūriu tarp normalios genialaus žmogaus būsenos ir patologinès - bepročio yra daug sąlyčio taškų. Tarp genialiu žmonių aptinkami pamišę ir tarp pamišèliu - genijai. Tačiau buvo ir yra daugybẻ genialių žmonių, kuriems nèra būdingi netgi menkiausi beprotybès požymiai, išskyrus kai kuriuos nenormalumus jausmingumo srityje“ (Lambroso 1997: 217).

Akivaizdu, kad Lambroso teorija, kuri pasinėrè i daugybės menkai pažistamu kūrybingos asmenybès psichikos problemų tyrinëjima, meno psichologijai ir psichiatrijai dar tik žengiant pirmuosius žingsnius, kupina perlenkimu ir netikslumu, perdėm kategoriškų apibendrini$\mathrm{mu}$, kurie pirmiausia siejosi su pagrindinėmis išankstinėmis psichopatologinės koncepcijos nuostatomis, nuosekliu empirinių tyrinèjimu ir sistemingų klinikinių stebëjimų trūkumu. Kita vertus, italų mokslininkas nekritiškai pervertino rašytiniuose šaltiniuose pateikiamus daugybės geniju intelektualinès ir kūrybinès biografijos faktus, neretai tendencingai aptarinëjo paskirus kūrybingos asmenybės charakterio bruožus ir nepakankamai vertino daugybės kitų jų kūrybinio potencialo ir meninès kūrybos proceso savitumus lemiančiu veiksnių poveikį.

Nepaisant minètų trūkumu, Lambroso idëjos turëjo stiprų poveiki vèlesnèms genialumo ir psichinių patologijų sąsajų 
studijoms, kurias toliau plètojo jo sekèjai Nordau, Kretschmeris, Lange-Eichbaumas ir kiti. Pavyzdžiui, daugybès įvairių kultūros ir politinio gyvenimo sričių genialių kūrèjų ir menininkų intelektualines biografijas detaliai tyrinejjęs 11 tomu veikale Genie - Irrsinn und Ruhm (Genijus - beprotybe ir šlove, 1928) autorius Lange-Eichbaumas teigè, kad visų epochų genialiems menininkams būdingas polinkis i ivairias psichikos ligas nuo neurotinių susirgimų iki sudètingiausių psichikos ligų formų. Šio psichiatro tvirtu isitikinimu, daugelis psichinių sutrikimų pačios kūrybos vertei neturi didžiulio poveikio tol, kol ligos eiga neišsekina kūrybinių asmenybès išteklių. Lange-Eichbaumas, tarsi apibendrindamas savo pirmtako Lambroso idejjas, kategoriškai pareiškè, kad yra pasiryžęs irodyti, jog mažiausiai 83 procentai geniju yra „akivaizdūs psichopatai“.

\section{NORDAU IŠSIGIMIMO TEORIJA}

Itakingiausiu iš visų Lambroso sekèju tapo psichiatras, rašytojas ir politikas Maksas Nordau (1849-1923). Tikroji jo pavarde - Simonas Maximilianas Südfeldas. Jis buvo kilęs iš rabinų šeimos, tèvas buvo išeivis iš Vokietijos, îsikūręs Vengrijoje ir rašęs hebrajiškai eiles, motina - litvakè, augusi Rygoje. Vaikystejje gavęs tradicini žydų religinị išsilavinima, studijų metais atsiribojęs nuo ortodoksinio judaizmo, susižavejjo tuomet didžiuli populiarumą Vakaruose igavusiomis evoliucinèmis teorijomis. Baigęs Pešto universiteto medicinos fakulteta, būsimasis psichiatras $1873 \mathrm{~m}$. atvyko i Berlyna, kur po metu pakeitè pavardę i Nordau. Vedęs protestantę, kurị laiką gyveno ir elgèsi kaip asimiliuotas žydas, laikantis save vokiškos kultūros atstovu.

Tačiau 1880 m. persikèlè i Paryžių, kur pasinèrè i visai kitą kultūrinę ir meninę erdvę. Šiame pagrindiniame tuometinès Vakarų kultūros ir meno centre Nordau praleido didžiają ir produktyviausią savo gyvenimo dali dirbdamas iš pradžių austrų periodinio leidinio Neue Freie Presse korespondentu, o vèliau atsiduodamas ivvairioms kitoms jị dominusioms kūrybinès veiklos sritims, dažniausiai tiesiogiai susijusioms su psichiatrijos problemomis. Paryžietišku gyvenimo tarpsniu jis artimai bendradarbiavo su garsiu Freudo mokytoju J.-M. Charcot, tačiau laikè save nuosekliu Lambroso idejų sekejju. Po skandalingos Dreyfuso bylos $1895 \mathrm{~m}$. Nordau vèl radikaliai pakeitè savo pasaulèvoką ir, aktyviai izsitraukęs į stiprejjanti sionistini sąūdì, ilgainiui tapo vienu ittakingiausių jo vadovų. Tačiau nepaisant minètų intelektualinès biografijos metamorfozių, jo mokslinių tyrinejjimų centre dažniausiai buvo psichiatrijos ir psichopatologijos problemos.

Psichiatrinių tyrinejjimų srityje Nordau reiškèsi kaip Spenglerio ir Lambroso idèju šalininkas, veikale Entartung (Išsigimimas, 1892) išplètojęs savitą „Vakarų saulèlydžio" koncepcijos variantą. Jis prabilo apie šiuolaikinės urbanistinès Vakarų civilizacijos destruktyvų poveiki žmogaus psichikai ir skelbė neišvengiamą europietiškosios kultūros išsigimimą bei degeneratyvaus meno formų isigalèjimą. Minètas didžiulį šurmulį intelektua- 
linio elito ir menininkų aplinkoje sukèlęs veikalas prasidejo simbolinę ir konceptualią prasmę igavusia dedikacija, skirta Lambroso: „Aš jums skyriau šią knyga, entuziastingai rašè Nordau, - norėdamas džiaugsmingai padékoti ir pripažinti, kad be jūsų darbų ji niekuomet nebūtų parašyta. Pirmiausia taikliai Morelio idiegta sąvoka degeneracija jūsų darbuose meistriškai išplètota ir tapo veiksminga ivairiose srityse" (Nordau 1998: vol. 1 V.). Minètame veikale pagrindinis dèmesys sutelkiamas į negatyvius socialinius, medicininius modernios urbanistinès civilizacijos poveikio žmogaus psichikai ir meninès kultūros raidai aspektus.

Aptardamas amžiaus pabaigoje Vakarų kultūroje išryškejjusius dekadentinius meno nuosmukio, medicininiais terminais tariant, „išsigimimo ligos" simptomus, Nordau atkreipe demesị ir į tradicinių vertybių bei moralès normų irima, kuris atsispindejjo liguistas formas igaunančioje fin de siècle kultūroje ir mene. Terminas "išsigimimas“ čia siejamas su nukrypimu nuo normos dèl paveldimu priežasčių. Nordau, kalbėdamas apie šiuos procesus, pirmiausia turi omenyje ne fizinį, o būtent psichini išsigimima, kurio svarbiausiais išoriniais požymiais tampa psichikos liguistumas, greitas susijaudinimas, bejègiškumas, nusivylimas, pasireiškiantis pasaulěžiūriniu pesimizmu, polinkis i melancholija, misticizma, nesugebejjimas priešintis ìvairioms persekiojančioms melagingoms idejjoms.

Nordau detaliai aptarinèjo prancūzų simbolistų, natūralistų, anglų prerafaelitų, dekadentų, estetizmo šalininkų, garsių rašytojų (S. Mallarmé, P. Verlaine'o, M. Maeterlincko, D. G. Rosseti,
L. Tolstojaus, R. Wagnerio, F. Nietzsche's, O. Wilde'o, H. Ibseno, E. Zola) kūrinius, kuriuose ižvelgè akivaizdžius išsigimimo bruožus. Iš čia kilo programinis jo teiginys: „Degeneracija paliečia ne vien tik kriminalinius asmenis, prostitutes, anarchistus, psichinius ligonius, tačiau ir pažeistos psichikos rašytojus bei menininkus. Šis didžiulis skaičius žmonių pasižymi tais pačiais intelektualiniais bruožais - ir yra viršugalvyje tų pačiu kūnišku problemu, kaip ir kiti tos pačios antropologinès šeimos nariai, kurie patenkina savo kenksmingus sveikatai instinktus žudančiu pervargimu, panašiai kaip kad dèžè su sprogstamosiomis dinamito medžiagomis" (ten pat: V-VI).

Šio dekadentizmo šauklio teorijoje jaučiamas ir F. Galtono ideju poveikis, o kartais ir užslèpta polemika su jo platų atgarsi igavusia genijaus sugebejjimu paveldimumo teorija. Gvildendamas genijaus ir talento psichofiziologijos problemas, Nordau teigè, kad keliu gabiu talentu atsiradimas toje pačioje šeimoje ne tik neirodo talento paveldimumo, bet ir įrodo, kad kiekvienoje šeimoje, tradiciškai turinčioje profesiją, normaliai išsivystęs vaikas gali tapti talentingu tik veikiamas pavyzdžio, nes tam nereikia jokios specialios organinès struktūros" (Nordau 1908).

Kitame savo veikale Entartung und Genie (Ǐssigimimas ir genijus, 1894) Nordau daugiausia dèmesio sutelkè i genijaus ir talento psichofiziologija, aiškinosi ju pagrindinius tipologinius bruožus, išryškino kūrybinio potencialo panašumus, skirtumus, sąsajas su psichinėmis ligomis sergančiais asmenimis. Talentas, Nordau ìsitikinimu, yra veikla, kurią paprastai 
geriau praktiškai atlieka dauguma žmonių, turinčiu gabumus, o genijus jau yra kokybiškai aukštesnis sugebëjimas kurti anksčiau neegzistavusius kūrinius, kuriems būdingas savitumas ir asmeniškumas. Esminiu talento ir genialumo skirtumu jis laikè "genijaus neatsiejamą ryši su neurozèmis" (Nordau 1897: 91).

Vadinasi, apibūdindamas genialumo esmę Nordau tarsi susiejo sunkiai suderinamus racionalisto Kanto ir voliuntarizmo ideologo Schopenhauerio bei Nietzsche's požiūrius. Jis, kaip ir pastarasis, buvo i̇sitikinęs neišvengiama Vakarų civilizacijos krize ir teigè, kad greta sveiko proto valia yra svarbiausias bruožas tokios genialios asmenybès, kuri dar suranda savyje jëgų priešintis visuotiniam kultūros ir meno destrukcijos procesui.

Taigi glaustai aptarę kelių itakingiausių psichopatologinių teorijų šalininkų koncepcijas galime konstatuoti, kad ju

\section{Literatūra}

Gros Fréderic. 1997. Création et folie. Une histoire du jugement psychiatrique. Paris: PUF.

Jaspers Karl. 1970. Strindberg et Van Gogh, Swedenborg et Hölderlin. Etude psichiatrique comparative. Paris: Minuit.

Kretschmer Ernst. 1963. Paranoïa et sensibilité. Paris: PUF.

Lombroso. 1997: Ломброзо Чезаре. Гениальность и помешательство. Ростов-на-Дону: Феникс.

Moreau de Tours J.-J. 1859. La psychologie morbide dans ses rapports avec la philosophie de l'histoire ou de l'influence des névropathies sur le dynamisme intellectuel. Paris: V. Masson.

Moreau de Tours Joseph. 1974. Du hachich et de atstovai toliau savitai plètojo romantikų ir neklasikinès meno filosofijos atstovų Schopenhauerio ir Nietzsche's veikaluose išryškëjusias genialumą ir psichikos ligas suartinusias koncepcijas. Čia i pirmą vietą iškilo įvairūs psichinių patologijų paveikti menininko kūrybinio potencialo ir meninès kūrybos proceso psichologijos aspektai. Juos aptardami žymiausi šios krypties atstovai akcentavo įvairius psichinėmis ligomis segančių kūrèjų išskirtinių sugebejjimų pasireiškimo ir sklaidos dèsningumus. Vis dèlto jie pateikè daug taiklių, ypač su menininkų kūrybiniu potencialu ir meninès kūrybos procesu susijusių ižvalgų. Pastebėjo daug kūrybinès veiklos dèsningumų, tačiau dažniausiai akcentuodami savo išankstines teorines nuostatas, jie nepakankamai daug dėmesio skyrè savo teorijų nuosekliam empiriniam ir statistiniam pagrindimui.

l'aliénation mentale. Recherches sur les aliénés en Orient, ed. Kesselring, Yverdon (Siusse).

Moreau Joseph. 1856. Psychologie morbide dans ses raports avec la philosophie de l'histoire. Paris, 1856.

Nietzsche Friedrich. 1991. Rinktiniai raštai. Vilnius: Mintis.

Nordau Max. 1897. Psycho-physiologie du génie et du talent. Paris: Felix Alcan.

Nordau Max. 1998. Dégénérescence. Genève: Slatkine reprints, 1998, vol. 1.

Ribot Théodule-Armand. 1885. Les Maladies de la personnalité. Paris: Félix Alcan.

Schopenhauer Arthur. 1995. Pasaulis kaip valia ir vaizdinys. Vilnius: Pradai. 